\title{
Kepuasan Kerja sebagai Mediasi Pengaruh Kualitas Kehidupan Kerja terhadap Kinerja Karyawan pada Usaha Kafe di Kota Malang
}

\author{
Sandra Irawati \\ Program Studi Manajemen, Universitas Muhammadiyah Malang \\ Jalan Raya Tlogomas No.246, Malang, Indonesia \\ irawati@umm.ac.id \\ Khusnul Rofida Novianti* \\ Program Studi Manajemen, Universitas Muhammadiyah Malang \\ Jalan Raya Tlogomas No.246, Malang, Indonesia \\ khusnulrofida@umm.ac.id
}

Diterima: 16-12-2020 | Disetujui: 24-12-2021 | Dipublikasi: 31-01-2022

\begin{abstract}
ABSTRAK
Penelitian ini bertujuan untuk mendeskripsikan kualitas kehidupan kerja, kepuasan kerja dan kinerja karyawan pada usaha kafe dan resto di Kota Malang. Menjelaskan pengaruh kualitas kehidupan kerja terhadap kinerja karyawan; pengaruh kualitas kehidupan kerja terhadap kepuasan kerja karyawan, pengaruh kepuasan kerja terhadap kinerja karyawan, serta menjelaskan peran kepuasan kerja dalam memediasi pengaruh kualitas kehidupan kerja terhadap kinerja karyawan. Pengambilan data dilakukan dengan menyebar kuesioner kepada 100 orang karyawan kafe di Kota Malang menggunakan analisis Jalur. Hasil penelitian menunjukkan kualitas kehidupan kerja karyawan kafe dalam kategori baik. Karyawan merasa puas terkait dengan pekerjaan, upah/gaji, kondisi kerja, rekan sekerja dan kesesuaian kepribadian dengan pekerjaannya. Kinerja karyawan kafe dari sisi proses kerja termasuk dalam kategori tinggi. Kualitas kehidupan kerja secara positif signifikan berpengaruh terhadap kinerja karyawan. Kualitas kehidupan kerja secara positif signifikan berpengaruh terhadap kepuasan kerja karyawan. Kepuasan kerja karyawan secara positif signifikan berpengaruh terhadap kinerja karyawan. Kepuasan kerja secara signifikan memediasi pengaruh kualitas kehidupan kerja terhadap kinerja karyawan.
\end{abstract}

Kata Kunci:

Kualitas Kehidupan Kerja; Kepuasan Kerja; Kinerja Karyawan

\begin{abstract}
This research tries to describe the quality of work-life, job satisfaction, and employee performance in cafe and restaurant businesses in Malang. Explain the influence of the quality of work-life on employee performance; the impact of the quality of work-life on employee job satisfaction; the effect of job satisfaction on employee performance; explain the role of the job satisfaction in mediating the influence of the quality of work-life on employee performance. Collected data were by distributing questionnaires to 100 cafe employees in the city of Malang. The analytical tool used is Path Analysis. The results showed that the cafe employees' work-life quality was in a good category. Employees feel satisfied concerning work, wages/salaries, working conditions, coworkers, and personal suitability with their work. The cafe employee's performance in terms of work processes is high. The quality of work-life has a significant positive effect on employee performance and job satisfaction. Then employee job satisfaction has a significant positive impact on employee performance. Job satisfaction significantly mediates the influence of the quality of work-life on employee performance.
\end{abstract}

Keywords:

Quality of Work-Life; Job Satisfaction; Employee Performance 


\section{PENDAHULUAN}

Keberhasilan sebuah usaha sangat dipengaruhi oleh peran seluruh karyawan yang dimilikinya. Berkenaan dengan hal tersebut, perusahaan bertanggung jawab terhadap pemantauan kinerja karyawan secara keseluruhan untuk menjawab pertanyaan apakah mereka sudah melakukan tugas dan kewajibannya sesuai dengan yang diharapkan. Kinerja karyawan adalah hasil kerja secara kuantitatif maupun secara kualitatif yang dapat dicapai oleh seorang karyawan sesuai dengan kewenangan dan tanggung jawabnya dalam mencapai tujuan-tujuan organisasi baik sebagai individu maupun sebagai anggota kelompok (Moeheriono, 2012.). Baik buruknya kinerja karyawan dipengaruhi oleh banyak faktor, seperti kualitas kehidupan kerja, motivasi kerja, kompensasi, sikap disiplin, kepemimpinan, komunikasi dan lingkungan kerja. Kualitas kehidupan kerja berperan penting terhadap berjalannya aktivitas kerja, dimana terjadi kesepakatan-kesepakatan antara pimpinan dan bawahan dalam pelaksanaan kegiatan. Kualitas kehidupan kerja yang baik berdampak pada perbaikan kepuasan kerja karyawan, kesehatan dan keselamatan kerja, kinerja karyawan, pembelajaran organisasi dan manajemen perubahan (Luthans, 2013.). Beberapa penelitian terdahulu menjelaskan tentang pengaruh kualitas kehidupan kerja terhadap kepuasan kerja dan kinerja menghasilkan kesimpulan yang berbeda. Sebuah penelitian yang dilakukan terhadap karyawan rumah sakit menyatakan bahwa kualitas kehidupan kerja diidentifikasi sebagai variabel yang berpengaruh positif dan signifikan terhadap kepuasan kerja dan kinerja karyawan rumah sakit (Gayathiri \& Ramakrishnan, 2013.). Penelitian lain menyatakan bahwa kualitas kehidupan kerja yang terdiri dari perilaku supervisi, kompensasi, tunjangan dan keseimbangan kehidupan kerja berpengaruh positif signifikan terhadap kepuasan kerja dan kinerja karyawan (Basher Rubel \& Kee, 2014.).

Kualitas kehidupan kerja berpengaruh terhadap kinerja karyawan melalui kepuasan kerja (Pamungkas, 2016.). Hal tersebut bermakna bahwa semakin baik kualitas kehidupan kerja semakin tinggi kepuasan kerja dan semakin tinggi kepuasan kerja semakin tinggi kinerja karyawan. Berbeda dengan penelitian dari (Pamungkas, 2016.), dinyatakan bahwa kepuasan kerja tidak memediasi pengaruh kualitas kehidupan kerja terhadap kinerja karyawan. Hasil temuan menjelaskan bahwa kualitas kehidupan kerja berpengaruh langsung terhadap kinerja karyawan dan tidak berpengaruh terhadap kepuasan kerja (Setiyadi et al., 2016.). Sebuah penelitian yang dilakukan pada karyawan hotel berbintang menjelaskan bahwa kualitas kehidupan kerja secara signifikan berpengaruh terhadap kinerja karyawan yang dimediasi oleh kepuasan kerja dan motivasi kerja (Sari, Bendesa \& Antara, 2019.). Sementara itu, penelitian yang dilakukan pada civitas akademika universitas menunjukkan bahwa kualitas kehidupan kerja dan kepemimpinan berpengaruh tidak langsung terhadap kinerja karyawan melalui kepuasan kerja (Arsyad, Maarif \& Sukmawati, 2020.).

Kota Malang sebagai Kota Pendidikan dan Kota Pariwisata membuat bisnis kafe tumbuh secara pesat. Badan Pelayanan Pajak Daerah (BP2D) Kota Malang mencatat, saat ini ada 144 kafe di Kota Malang. Bisnis ini tumbuh seiring dengan banyaknya jumlah mahasiswa yang datang di Kota tersebut. 
Berdasarkan data kependudukan, pertumbuhan jumlah mahasiswa berkisar 5 hingga 10 persen pertahun. Jumlah ini tentunya cukup besar dan bisnis kafe mampu memenuhi kebutuhan mahasiswa saat ini sebagai tempat untuk bersantai ataupun sebagai tempat untuk berdiskusi dan menyelesaikan tugas-tugas perkuliahan. Bisnis kafe di Kota Malang banyak didirikan oleh generasi milenial sehingga mereka paham betul bagaimana mengemas kafe mereka sesuai dengan kebutuhan generasi milenial saat ini. Bisnis ini juga menyerap banyak tenaga kerja dari generasi milenial, baik dari pelajar maupun mahasiswa. Hal tersebut tentu saja menarik untuk diteliti berkaitan dengan ciri-ciri generasi milenial dalam bekerja. Kebanyakan kafe beroperasi siang sampai malam hari, sedangkan karyawan kafe kebanyakan mahasiswa yang bekerja sambil kuliah. Tentu saja hal ini tidaklah mudah mengelola mereka sehingga berkinerja tinggi. Beberapa pemilik kafe menyerahkan pengelolaan kafe ke anak-anak muda milenial, sehingga mereka bisa terlibat secara aktif mengembangkan bisnis ini sesuai dengan tuntutan konsumennya. Keterlibatan ini menjadi hal positif bagi karyawan kafe, sesuai dengan ciri mereka sebagai generasi milenial yang menyukai keterlibatan tinggi dalam bekerja. Namun disisi yang lain, karyawan kafe dihadapkan pada kondisi kerja yang tidak aman secara psikologis. Penelitian ini berusaha untuk mengidentifikasi pengaruh kualitas kehidupan kerja terhadap kinerja karyawan kafe di Kota Malang dengan kepuasan kerja sebagai variabel mediasi.

Kualitas kehidupan kerja (Quality of Worklife) merupakan suatu pendekatan sistem manajemen dalam organisasi yang bertujuan untuk melakukan peningkatan kualitas kehidupan karyawan dalam lingkungan kerja secara simultan dan berkesinambungan. Kualitas kehidupan kerja dapat dijalankan dengan memberikan perasaan aman dalam bekerja, perasaan dihargai serta perasaan tumbuh kembang dalam bekerja sehingga meningkatkan harkat dan martabat karyawan. Kualitas kehidupan kerja adalah dinamika multidimensional yang meliputi beberapa konsep, seperti jaminan kerja, sistem penghargaan, pelatihan, karir, peluang kemajuan dan keikutsertaan dalam pengambilan keputusan (Robbin, 2015.). Tujuan dari dibangunnya kualitas kehidupan kerja adalah dalam rangka memperbaiki kepuasan kerja karyawan, memperbaiki keselamatan kerja, meningkatkan kinerja karyawan, menciptakan pembelajaran organisasi, dan mendukung manajemen perubahan. Selanjutnya untuk mengukur tinggi rendahnya kualitas kehidupan kerja dikembangkan dimensi-dimensi sebagai kesehatan dan kesejahteraan pekerja, keamanan kerja, pengembangan kompetensi karyawan, serta keseimbangan antara pekerjaan dan non pekerjaan (Luthans, 2013.). Penelitian Arifin (2012) menjelaskan bahwa kualitas kehidupan kerja berpengaruh positif signifikan terhadap kinerja karyawan. Sementara itu penelitian Lumbantoruan (2015) menemukan bahwa kualitas kehidupan kerja, kepuasan kerja dan komitmen organisasional berpengaruh positif dan signifikan terhadap kinerja karyawan. Dua hasil penelitian tersebut menjelaskan bahwa semakin baik kualitas kehidupan kerja, semakin tinggi kinerja karyawan. Penelitian yang dilakukan oleh (Basher Rubel \& Kee, 2014.) menemukan bahwa kualitas kehidupan kerja yang dilihat dari perilaku supervisor, kompensasi, tunjangan dan karakter pekerjaan berpengaruh positif dan signifikan terhadap kepuasan kerja. Sedangkan penelitian Alfani (2018) menyatakan bahwa Quality of work life berpengaruh signifikan terhadap kinerja karyawan, Quality of 
work life berpengaruh signifikan terhadap kepuasan kerja karyawan. Dua temuan tersebut menjelaskan bahwa semakin baik kualitas kehidupan kerja, semakin tinggi kepuasan kerja karyawan. Sehingga hipotesis yang diajukan:

H1: kualitas kehidupan kerja berpengaruh positif signifikan terhadap kinerja karyawan.

Robbin (2015) menyatakan bahwa faktor-faktor kepuasan kerja terdiri dari pekerjaan yang secara mental menantang, ganjaran yang pantas, kondisi kerja yang mendukung, rekan kerja yang mendukung serta kesesuaian kepribadian dengan pekerjaan. Selanjutnya dijelaskan bahwa kepuasan kerja memiliki dampak terhadap kinerja karyawan yang meliputi produktivitas, tingkat kemangkiran dan tingkat keluarnya karyawan. Beberapa sudut pandang dalam melihat kepuasan kerja mengungkapkan kepuasan kerja dalam beberapa perspektif yang berbeda yakni teori dua faktor (Two Factor Theory) yang mengemukakan bahwa kepuasan dan ketidakpuasan, berada pada kuadran yang berbeda. Lawan dari kepuasan bukanlah ketidakpuasan, tetapi tidak ada kepuasan. Sebaliknya lawan dari ketidakpuasan bukanlah kepuasan, tetapi tidak ada ketidakpuasan. Kepuasan kerja berkaitan dengan faktor motivator sedangkan ketidakpuasan kerja berkaitan dengan faktor hygiene. Teori Nilai (Value Theory) menyatakan bahwa kepuasan kerja terjadi di tingkatan di mana hasil pekerjaan diterima oleh individu seperti yang diharapkan. Jika hasil yang diterima semakin banyak, maka semakin puas dan sebaliknya. Teori ketidaksesuaian, menyatakan bahwa setiap orang menginginkan agar sejumlah pekerjaan yang telah disumbangkan di tempat kerja sepadan antara harapan dengan kenyataan. Teori keadilan menyatakan bahwa seseorang merasa puas jika ada perasaan adil sedangkan ketidakpuasan muncul jika ada ketidakadilan.

Kinerja karyawan merupakan hasil kerja yang dapat dicapai oleh seorang karyawan atau kelompok orang dalam suatu perusahaan sesuai dengan wewenang dan tanggung jawab masing-masing dalam upaya pencapaian tujuan perusahaan. Faktor-faktor yang mempengaruhi kinerja karyawan meliputi: kemampuan, motivasi, dukungan yang diterima, lingkungan kerja, ketersediaan peralatan dan barang, job deskripsi dan tanggung jawab, kepuasan terhadap pekerjaan (Rivai, 2014.). Selanjutnya, Robbin (2015) mengemukakan 6 dimensi untuk mengukur kinerja pegawai secara individu, yaitu kualitas kerja, kuantitas kerja ketepatan waktu dalam menyelesaikan aktivitas, efektivitas penggunaan sumber daya, kemandirian dalam bekerja serta komitmen terhadap pekerjaan. Pamungkas (2016) dalam hasil penelitiannya menyatakan kepuasan kerja berpengaruh positif dan signifikan terhadap kinerja karyawan. Sari, Bendesa \& Antara (2019) menemukan kepuasan kerja dan motivasi kerja berpengaruh positif dan signifikan terhadap kinerja karyawan. Hasil penelitian tersebut bermakna bahwa semakin puas karyawan dalam bekerja, semakin tinggi kinerja karyawan tersebut. Arsyad, Maarif \& Sukmawati (2020) memberikan hasil temuan bahwa kualitas kehidupan kerja secara signifikan berpengaruh tidak langsung terhadap kinerja tenaga kependidikan melalui kepuasan kerja. Penelitian Arsyad, Maarif \& Sukmawati (2020) juga menyatakan bahwa kualitas kehidupan kerja berpengaruh terhadap kinerja karyawan melalui kepuasan kerja, sehingga hipotesis yang diajukan adalah

H2: kualitas kehidupan kerja berpengaruh positif signifikan terhadap kepuasan karyawan 
H3: kepuasan kerja berpengaruh signifikan terhadap kinerja karyawan

H4: kepuasan kerja secara signifikan memediasi pengaruh kualitas kehidupan kerja terhadap kinerja karyawan.

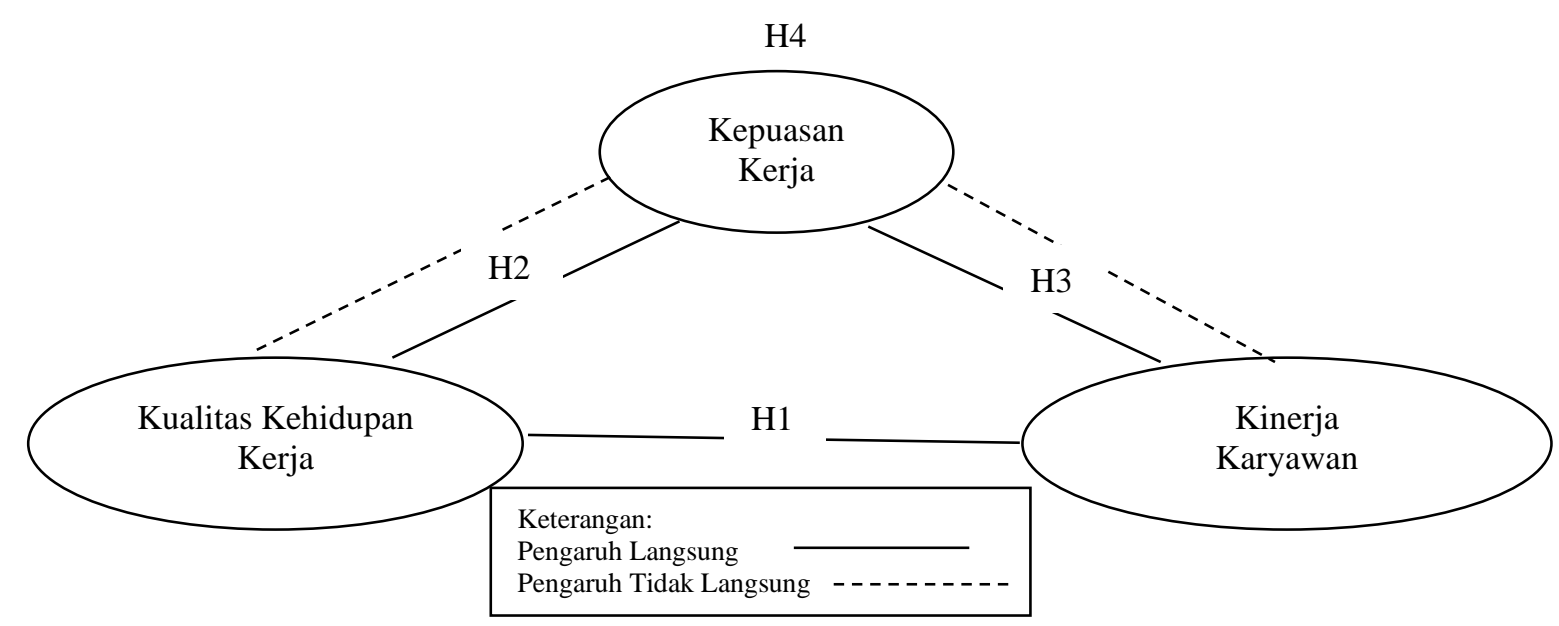

Gambar 1. Kerangka Penelitian

\section{METODE RISET}

Penelitian ini berupa penelitian deskriptif kuantitatif dengan populasi penelitian berupa karyawan kafe milenial yaitu usaha kafe yang dikelola oleh generasi milenial di wilayah Kota Malang yang jumlahnya belum diketahui secara pasti. pengambilan sampel dilakukan dengan menggunakan teknik non probability sampling dalam hal ini convenience sampling dengan jumlah sampel 100 karyawan kafe dengan berpatok pada (Hair et al., 2014.) yang menjelaskan bahwa penetapan jumlah sampel minimal dengan variabel $\leq 5$ maka jumlah sampel yang harus dipenuhi sebesar 100 , sedangkan untuk variabel $\leq 7$ minimal sebesar 150 , variabel $\geq 7$ minimal sebesar 300 , dan model dengan variabel yang sangat banyak minimal sebesar 500. Indikator yang digunakan dalam penelitian ini adalah kualitas kehidupan kerja (keamanan kondisi kerja, keterlibatan kerja, kebijakan pengembangan karir serta keadilan dalam pemberian kompensasi) (Basher Rubel \& Kee, 2014.). Kepuasan kerja diukur dengan perasaan karyawan tentang tantangan dalam bekerja, kepantasan pemberian kompensasi, rekan kerja, kondisi kerja, serta kesesuaian kepribadian dengan pekerjaannya (Robbin, 2015.). Kinerja karyawan diukur dengan semangat kerja, upaya melayani dengan baik, pemahaman terhadap aturan, kerjasama, inisiatif, kemandirian, pengetahuan, keterampilan, tanggung jawab, keluwesan, upaya maksimal memenuhi standar kerja dan kebanggaan terhadap pekerjaan (Arsyad, Maarif \& Sukmawati, 2020.). Pengumpulan data menggunakan kuesioner dengan Skala Likert. Penelitian ini menggunakan analisis jalur (path analysis) untuk menganalisis data dengan terlebih dahulu menguji validitas, reliabilitas, serta uji hipotesis. 


\section{HASIL PENELITIAN DAN PEMBAHASAN}

Hasil pengumpulan 100 responden yang dikumpulkan dapat disimpulkan bahwa mayoritas responden didominasi laki-laki (63\%), berusia antara 22-24 tahun, dengan pendidikan mayoritas SMA/SMK (59\%) dengan masa kerja antara 1-2 tahun disajikan dalam tabel 1 berikut:

Tabel 1. Demografi Responden

\begin{tabular}{|c|c|c|c|}
\hline \multicolumn{2}{|c|}{ Demografi Responden } & \multirow{2}{*}{$\begin{array}{c}\begin{array}{c}\text { Jumlah } \\
(\mathrm{N}=100)\end{array} \\
24\end{array}$} & \multirow{2}{*}{$\begin{array}{c}\text { Prosentase } \\
24 \%\end{array}$} \\
\hline Usia & $19-21$ tahun & & \\
\hline & $22-24$ tahun & 43 & $43 \%$ \\
\hline & $25-28$ tahun & 33 & $33 \%$ \\
\hline \multirow[t]{2}{*}{ Jenis Kelamin } & Laki-Laki & 63 & $63 \%$ \\
\hline & Perempuan & 37 & $37 \%$ \\
\hline \multirow[t]{3}{*}{ Pendidikan } & SMA/SMK & 59 & $59 \%$ \\
\hline & Diploma & 16 & $16 \%$ \\
\hline & S-1 & 25 & $25 \%$ \\
\hline \multirow[t]{3}{*}{ Status } & Lajang & 38 & $38 \%$ \\
\hline & Menikah & 27 & $27 \%$ \\
\hline & Mahasiswa & 35 & $35 \%$ \\
\hline \multirow[t]{3}{*}{ Masa Kerja } & $<1$ tahun & 11 & $11 \%$ \\
\hline & $1-2$ tahun & 79 & $79 \%$ \\
\hline & $>2$ tahun & 10 & $10 \%$ \\
\hline
\end{tabular}

Pengujian instrumen penelitian dilakukan dengan menguji validitas dan reliabilitas variabel kualitas kehidupan kerja, kepuasan kerja dan kinerja karyawan pada tabel 2.

Tabel 2. Uji Validitas

\begin{tabular}{ccccc}
\hline Variabel & Indikator & r hitung & r tabel & Ket. \\
\hline Kualitas Kehidupan Kerja (X) & X1 & 0,625 & & Valid \\
& X2 & 0,531 & & Valid \\
& X3 & 0,672 & 0,254 & Valid \\
& X4 & 0,713 & & Valid \\
Kepuasan Kerja (Z) & Z1 & 0,723 & & Valid \\
& Z2 & 0,600 & & Valid \\
& Z3 & 0,673 & & Valid \\
Zinerja Karyawan (Y) & Z5 & 0,668 & 0,254 & Valid \\
& Y1 & 0,706 & & Valid \\
& Y2 & 0,628 & & Valid \\
& Y3 & 0,631 & & Valid \\
& Y4 & 0,671 & & Valid \\
& Y5 & 0,791 & & Valid \\
& Y6 & 0,686 & \multirow{2}{*}{0,254} & Valid \\
& Y7 & 0,700 & & Valid \\
& Y8 & 0,726 & & Valid \\
& Y9 & 0,711 & & Valid \\
& Y10 & 0,568 & & Valid \\
& Sumber: Datadiolah 2020 & & Valid \\
\hline
\end{tabular}

Uji reliabilitas dilakukan menggunakan nilai Cronbach's Alpha dengan ketentuan Alpha $<0.50$ reliabilitas rendah; $0.50<$ Alpha $<0.70$ reliabilitas moderat; Alpha $>0.80$ reliabilitas kuat; Alpha $>0.90$ reliabilitas sempurna pada tabel 3 : 
Irawati, S. \& Novianti, K.R. (2022). Kepuasan Kerja sebagai Mediasi Pengaruh Kualitas ....

Tabel 3. Uji Reliabilitas

\begin{tabular}{lccc}
\hline Variabel & Nilai Alpha & Alpha pembanding & Ket. \\
\hline Kualitas Kehidupan Kerja (X) & 0,911 & 0,600 & Reliabel \\
Kepuasan Kerja (Z) & 0,903 & 0,600 & Reliabel \\
Kinerja Karyawan (Y) & 0,866 & 0,600 & Reliabel \\
\hline
\end{tabular}

Sumber: Data diolah, 2020

Hasil uji normalitas menunjukkan bahwa nilai Asymp Sig (2-tailed) adalah 0,418 nilai ini lebih besar dari nilai signifikansi 0,05, maka dapat disimpulkan data penelitian berdistribusi normal (tabel 4).

Tabel 4. Uji Normalitas

\begin{tabular}{llr}
\hline $\mathrm{N}$ & & 100 \\
\hline Normal Parameters & Mean & .0000000 \\
& Std. Deviation & 36.61164084 \\
& Absolute & .088 \\
Most Extreme Differences & Positive & .088 \\
& Negative & -.048 \\
Kolmogorov-Smirmov $Z$ & & .882 \\
Asymp Sig. (2-tailed) & & .418 \\
\hline
\end{tabular}

Sumber: Data diolah, 2020

Nilai Variance Inflation Factor (VIF) untuk variabel kualitas kehidupan kerja, kepuasan kerja dan kinerja karyawan semuanya bernilai kurang dari 10 dan nilai toleransi lebih dari 0.01 maka dapat disimpulkan bahwa tidak ada gejala multikolinearitas.

Tabel 5. Uji Multikolinieritas

\begin{tabular}{lcc}
\hline \multicolumn{1}{c}{ Model } & \multicolumn{2}{c}{ Collinearity } \\
& Tolatistic \\
& 0,999 & VIF \\
\hline Kualitas Kehidupan Kerja & 1.001 \\
Kepuasan Kerja & 0,956 & 1.046 \\
Kinerja Karyawan & 0,956 & 1.046 \\
\hline
\end{tabular}

Sumber: Data diolah, 2020

Hasil pengujian menunjukkan nilai signifikansi: variabel kualitas kehidupan kerja sebesar 0,234, variabel kepuasan kerja 0,262 dan interaksi kedua variabel tersebut sebesar 0,273 dan semuanya memiliki nilai lebih besar dari 0,05 , artinya tidak terdapat heteroskedastisitas.

Tabel 6. Uji Heteroskedastisitas

\begin{tabular}{lccccc}
\hline \multicolumn{5}{c}{ Model } & \multicolumn{5}{c}{ Unstandardised coefficients } \\
\hline & $B$ & Std Error & Beta & $t$ & Sig \\
(Constant) & -169.54 & 158.61 & & -1.069 & .288 \\
Kualitas Kehidupan Kerja (X) & 2.854 & 2.385 & .995 & 1.197 & .234 \\
Kepuasan Kerja (Z) & 3.412 & 3.025 & .753 & 1.128 & .262 \\
Kinerja Karyawan & -.049 & .045 & -1.43 & -1.102 & .273 \\
\hline \multicolumn{5}{c}{ Sumber: Data diolah, 2020} \\
\end{tabular}

Hasil uji jalur hipotesis pertama didapatkan nilai t hitung sebesar 6.284 sehingga dinyatakan bahwa kualitas kehidupan kerja berpengaruh signifikan terhadap kinerja karyawan. Hasil tersebut dapat diperkuat dengan hipotesis 1 yang menyatakan bahwa kualitas kehidupan kerja berpengaruh positif dan signifikan terhadap kinerja karyawan dapat diterima kebenarannya karena nilai t hitung sebesar 6.892 lebih besar dari nilai t tabel sebesar 1.660 dan nilai signifikansi sebesar 0.000 lebih kecil dari taraf signifikan 0.05 . Hal tersebut bermakna bahwa semakin baik kualitas kehidupan kerja, semakin tinggi 
kinerja karyawan. Hasil ini mendukung penelitian sebelumnya bahwa kualitas kehidupan kerja berpengaruh positif dan signifikan terhadap kinerja karyawan (Arifin, 2012.; Gayathiri \& Ramakrishnan, 2013.; Lumbantoruan, 2015.).

Tabel 7. Pengaruh Langsung Variabel

\begin{tabular}{|c|c|c|c|c|c|}
\hline Model & \multicolumn{5}{|c|}{ Unstandardized Coefficients } \\
\hline & $B$ & Std Error & Beta & $t$ & Sig \\
\hline (Constant) & 20.210 & 3.216 & & 6.284 & .000 \\
\hline $\mathrm{X} \rightarrow \mathrm{Y}$ & 0.318 & .046 & .571 & 6.892 & .000 \\
\hline$X \rightarrow Z$ & 0.344 & .054 & .542 & 6.389 & .000 \\
\hline $\mathrm{Z} \rightarrow \mathrm{Y}$ & 0.594 & .065 & .675 & 9.067 & .000 \\
\hline $\mathrm{R}$ & 0.675 & & & & \\
\hline$R$ Square & 0.456 & & & & \\
\hline Adjusted R Square & 0.451 & & & & \\
\hline
\end{tabular}

Temuan hipotesis 2 menyatakan bahwa kualitas kehidupan kerja berpengaruh positif dan signifikan terhadap kepuasan kerja karyawan dapat diterima kebenarannya karena nilai t hitung sebesar 6.389 lebih besar dari nilai t tabel 1.660 dengan nilai signifikansi 0.000 lebih kecil dari 0.05. Pada jalur kedua ini diketahui bahwa kualitas kehidupan kerja berpengaruh positif dan signifikan terhadap kepuasan kerja karyawan. Hal tersebut bermakna bahwa apabila kualitas kehidupan kerja semakin baik, maka semakin tinggi kepuasan kerja karyawan. Hasil penelitian ini mendukung penelitian Basher Rubel \& Kee (2014).

Hipotesis 3 menyatakan bahwa kepuasan kerja berpengaruh positif dan signifikan terhadap kinerja karyawan juga dapat diterima kebenarannya karena nilai t hitung sebesar 9.067 lebih besar dari nilai t tabel 1.660 dengan nilai signifikan sebesar 0.000 lebih kecil dari taraf signifikan 0.05. Persamaan jalur ketiga menjelaskan bahwa kepuasan kerja berpengaruh positif dan signifikan terhadap kinerja karyawan. Hal tersebut bermakna bahwa semakin tinggi kepuasan kerja karyawan, maka semakin tinggi kinerja karyawan. Hasil penelitian ini mendukung penelitian Alfani (2018) serta Prabowo et al., (2018).

Tabel 8. Pengaruh Tidak Langsung

\begin{tabular}{lcccc}
\hline Model & $B$ & Std Error & $t$ & Sig \\
\hline $\mathrm{X} \rightarrow \mathrm{Y} \rightarrow \mathrm{Z}$ & 0.0739 & 0.0468 & 3.0135 & .005 \\
\hline \multicolumn{5}{c}{ Sumber: Data diolah, 2020}
\end{tabular}

Hasil temuan tersebut diperkuat hipotesis 4 yang menyatakan bahwa kepuasan kerja secara signifikan memediasi pengaruh kualitas kehidupan kerja terhadap kinerja karyawan dapat diterima kebenarannya karena dari perhitungan sobel test pada tabel 8 diperoleh nilai t hitung sebesar 3.0135 nilai ini lebih besar dari nilai t tabel 1.96 pada tingkat signifikansi 0.05 . Persamaan di jalur keempat ini menunjukkan bahwa kualitas kehidupan kerja dan kepuasan kerja berpengaruh positif dan signifikan terhadap kinerja karyawan. Semakin baik kualitas kehidupan kerja dan semakin tinggi kepuasan kerja maka semakin tinggi kinerja karyawan. Lebih lanjut, kepuasan kerja mampu memediasi secara sempurna atas pengaruh kualitas kehidupan kerja terhadap kinerja karyawan di usaha jasa kafe dan restoran yang ada di Kota Malang. Hal tersebut dapat dimaknai bahwa apabila semakin baik kualitas 
kehidupan kerja maka semakin tinggi kepuasan kerja dan semakin tinggi kepuasan kerja, maka semakin tinggi pula kinerja karyawan. Hasil penelitian ini sejalan dengan penelitian sebelumnya yang menyatakan bahwa kehidupan kerja dan kepuasan kerja berpengaruh positif dan signifikan terhadap kinerja karyawan (Basher Rubel \& Kee, 2014.; Pamungkas, 2016.; Sari, Bendesa \& Antara, 2019.).

\section{KESIMPULAN DAN SARAN}

Berdasarkan hasil penelitian dapat disimpulkan bahwa kualitas kehidupan kerja karyawan kafe dalam kategori baik, dilihat dari sistem pengupahan, kondisi kerja, kesempatan untuk berkembang, pemenuhan hak-hak pribadi karyawan, relasi sosial dan relevansi sosial kehidupan kerja. Kualitas kehidupan kerja berpengaruh positif dan signifikan terhadap kinerja karyawan. Hal tersebut bermakna bahwa semakin baik kualitas kehidupan kerja, semakin tinggi kinerja karyawan. Kualitas kehidupan kerja berpengaruh positif dan signifikan terhadap kepuasan kerja karyawan, yang bermakna bahwa apabila kualitas kehidupan kerja semakin baik, maka semakin tinggi kepuasan kerja karyawan. Selain itu, kepuasan kerja berpengaruh positif dan signifikan terhadap kinerja karyawan, berarti semakin tinggi kepuasan kerja karyawan, maka semakin tinggi kinerja karyawan. Selanjutnya, kepuasan kerja berperan memediasi pengaruh kualitas kehidupan kerja terhadap kinerja karyawan di usaha jasa kafe dan restoran yang ada di Kota Malang.

\section{Implikasi Penelitian}

Penelitian ini menekankan pentingnya aspek kepuasan kerja serta kualitas kehidupan kerja karyawan sebagai aspek penentu dalam meningkatkan kinerja karyawan, utamanya bagi pengelola jasa kafe dan restoran. Penelitian ini dapat menjadi gambaran terkait aspek kualitas kehidupan kerja apa saja yang perlu dipenuhi dan ditingkatkan bagi pengusaha jasa kafe dan restoran.

\section{Keterbatasan dan Saran}

Penelitian ini hanya menggunakan sampel minimum yakni karyawan kafe dan restoran dan hasil penelitian ini tidak dapat digeneralisasikan seluruh usaha jasa kafe dan restoran di di Kota Malang. Oleh karena itu, peneliti selanjutnya diharapkan mampu meneliti dengan menggunakan jumlah sampel yang lebih besar dan menggunakan aspek pengukuran yang lain. 


\section{DAFTAR PUSTAKA}

Alfani, M.H. (2018). Analisis Pengaruh Quality of Work Life (QWL) Terhadap Kinerja Dan Kepuasan Kerja Karyawan PT. Bank BRI Syariah Cabang Pekanbaru. Islamic Banking and Finance, 1(1), pp. 1-13. doi:10.25299/jtb.2018.vol1(1).2039.

Arifin, N. (2012). Analisis Kualitas Kehidupan Kerja, Kinerja, Dan Kepuasan Kerja Pada CV Duta Senenan Jepara. Jurnal Economia, 8(1), pp. 11-21. doi:10.21831/economia.v8i1.797.

Arsyad, M., Maarif, M.S. and Sukmawati, A. (2020). Effect of Quality of Work Life and Leadership on Job Satisfaction and Performance Workforce at the State University of Medan. Asian Journal of Social Sciences and Management Studies, 7(3), pp. 188-197. doi:10.20448/journal.500.2020.73.188.197.

Basher Rubel, M.R. and Kee, D.M.H. (2014). Quality of work life and employee performance: Antecedent and outcome of job satisfaction in partial least square (PLS). World Applied Sciences Journal, 31(4), pp. 456-467. doi:10.5829/idosi.wasj.2014.31.04.142.

Gayathiri, R. and Ramakrishnan, L. (2013). Quality of Work Life - Linkage with Job Satisfaction and Performance. International Journal of Business and Management Invention, 2(1), pp. 1-8.

Hair, J.F. et al. (2014) Multivariate Data Analysis. 7 edition. New York: Pearson Education Limited.

Lumbantoruan, E.R. (2015). Pengaruh Kualitas Kehidupan Kerja, Kepuasan Kerja dan Komitmen Karyawan dan Perilaku Kewargaan Sebagai Variabel Intervening (Studi Pada PT Perindustrian dan Perdagangan Crumb Rubber Pekanbaru). JOM FEKON, 2(1), pp. 1-10.

Luthans, F. (2013). Organizational Behavior: An Evidence-Based Approach. 12th edn. New York, NY, USA: McGraw-Hill/Irwin.

Moeheriono (2012). Pengukuran Kinerja Berbasis Kompetensi. Edisi Revisi. Jakarta: Raja Grafindo Perkasa.

Pamungkas, Y. (2016). Pengaruh Kualitas Kehidupan Kerja Terhadap Kinerja Dengan Kepuasan Kerja Sebagai Variabel Intervening (Studi pada Karyawan BPS Provinsi D.I. Yogyakarta). Jurnal Bisnis Teori dan Implementasi (JBTI), 7(2), pp. 221-250.

Prabowo, T.S., Noermijati and Irawanto, D.W. (2018). Leadership and Work Motivation on Employee Performance Mediated. Journal of Applied Management (JAM), 16(1), pp. 171-178. 
Irawati, S. \& Novianti, K.R. (2022). Kepuasan Kerja sebagai Mediasi Pengaruh Kualitas ....

Rivai, V. (2014). Manajemen Sumber Daya Manusia Untuk Perusahaan Dari Teori Ke Praktek. Jakarta: PT. Raja Grafindo Persada.

Robbin, J. (2015). Perilaku Organisasi. Jakarta: Salemba Empat.

Sari, N.P.R., Bendesa, I.K.G. and Antara, M. (2019). The Influence of Quality of Work Life on Employees' Performance with Job Satisfaction and Work Motivation as Intervening Variables in Star-Rated Hotels in Ubud Tourism Area of Bali. Journal of Tourism and Hospitality Management, 7(1), pp. 74-83. doi:10.15640/jthm.v7n1a8.

Setiyadi, Y.W. et al. (2016). Pengaruh Kualitas Kehidupan Kerja terhadap Kinerja Karyawan dengan Kepuasan Kerja sebagai Variabel Intervening. Management Analysis Journal, 5(4), pp. 315-324. doi:10.15294/maj.v5i4.12306. 